\title{
ANALISIS HUBUNGAN KINERJA APARATUR PEMERINTAH NAGARI TERHADAP PELAYANAN MASYARAKAT DI NAGARI LUNANG UTARA KECAMATAN LUNANG KABUPATEN PESISIR SELATAN
}

\author{
H. Mhd. Ikhsan, S.E, M.M \\ KPU Kota Sungai Penuh \\ email: \\ mhdikhsan@gmail.com
}

\begin{abstract}
The purpose of this study was to determine whether there is a relationship between the performance of the Nagari government officials to community services and to determine the level of the relationship between the performance of the Nagari government officials to community services in Nagari Lunang Utara, Lunang District, Pesisir Selatan Regency using a quantitative approach. The number of respondents in this study amounted to 80 people with the data collection technique is random sampling. The results in this study indicate that the product moment correlation from the calculation obtained a correlation coefficient of $r=0.65$ where this correlation coefficient is in the numerical interval of 0.600 - 0799 which means that it shows the level of a strong relationship and the magnitude of the relationship between the performance of the Nagari government apparatus to community services from the test. significance obtained by the $t$ value of 7.55 while the value of table with an error rate of $\alpha=0.05 \mathrm{db}=n-2=80-2=78$ is 1.66 so that tcount $>$ ttable is $7.55>1.66$ with Thus, based on the significant test criteria, Ha is accepted and Ho is rejected, meaning that there is a relationship between the performance of the Nagari government apparatus to community services in Nagari Lunang Utara, Lunang District, Pesisir Selatan Regency, West Sumatra Province.
\end{abstract}

Keywords: The performance of Village Government,Public Service

\begin{abstract}
ABSTRAK
Tujuan dari penelitian ini adalah untuk mengetahui apakah terdapat hubungan antara kinerja aparatur pemerintah nagari terhadap pelayanan masyarakat serta untuk mengetahui tingkat hubungan antara kinerja aparatur pemerintah nagari terhadap pelayanan masyarakat di Nagari Lunang Utara Kecamatan Lunang Kabupaten Pesisir Selatan dengan menggunakan pendekatan kuantitatif. Jumlah responden dalam penelitian ini berjumlah 80 orang dengan teknik pengumpulan data adalah pengambilan sampel secara acak. Hasil dalam penelitian ini menunjukan bahwa korelasi product moment dari perhitungan diperoleh koefisien korelasi sebesar $r=0,65$ dimana koefisien korelasi ini berada pada interval angka 0,600 - 0799 yang berarti menunjukan tingkat hubungan yang kuat serta besarnya hubungan kinerja aparatur pemerintah nagari terhadap pelayanan masyarakat dari uji signifikasi diperoleh nilai $t$ hitung sebesar 7,55 sedang kan nilai $t$ table dengan tingkat kesalahan $\alpha=0,05 d b=n-2=80-2=78$ adalah 1,66 sehingga $t_{\text {hitung }}>t_{\text {table }}$ yaitu 7,55 > 1,66 dengan demikian maka berdasarkan kriteria uji signifikan, Ha diterima dan Ho ditolak artinya bahwa ada terdapat hubungan antara kinerja aparatur pemerintah nagari terhadap pelayanan masyarakat di Nagari Lunang Utara Kecamatan Lunang Kabupaten Pesisir Selatan Provinsi Sumatera barat.
\end{abstract}

Kata kunci :Kinerja Aparatur Pemerintah Nagari, Pelayanan Masyarakat 


\section{PENDAHULAN}

\subsection{LatarBelakangMasalah}

Kinerja merupakan suatu hasil kerja yang dapat dicapai oleh seseorang atau kelompok orang dalam suatu organisasi sesuai dengan wewenang dan tanggung jawab masingmasing. Dalam mencapai tujuan organisasi bersangkutan secara legal, tidak melanggar hukum dan sesuai dengan moral dan etika. Tujuan utama kinerja pemerintahan yang baik adalah semuanya akan bermuara kepada kepentingan rakyat. Kinerja merupakan suatu gambaran tingkat pencapaian pelaksanaan dari kegiatan, program dan kebijakan dalam mewujudkan sasaran, tujuan, visi dan misi organisasi pemerintahan. Pentingnya suatu kinerja pemerintahan sangat menentukan terhadap keberlangsungan pemerintahan dan kualitas dari pelayanan masyarakat (publik).

Pelayanan publik merupakan salah satu tanggung jawab dari instansi pemerintah, baik itu di pusat, di daerah, maupun di desa. Pelaksanaan pelayanan publik ini merupakan salah satu fungsi pemerintah dalam melakukan kemudahan pada masyarakat dalam menggunakan hak dan kewajibannya. Dalam penyelenggaraan pelayanan oleh pemerintah, rasa puas masyarakat terpenuhi bila pelayanan yang diberikan oleh pemerintah kepada masyarakat sesuai dengan apa yang masyarakat harapkan dengan memberikan kinerja yang baik dari aparatur pemerintah tersebut, namun sebaliknya apabila kinerja dari aparatur pemerintah tidak maksimal maka akan menimbulkan rasa kecewa, keluhan dan sebagainya dari masyarakat yang akan mengakibatkan kurang efektif dan efisiennya pelayananan tersebut.

Pada saat ini pelayanan publik di desa atau di nagari banyak mendapat sorotan dari masyarakat. Dengan adanya kebebasan menyampaikan pendapat banyak ditemukan kritikan terhadap kinerja aparatur pemerintah Nagari, baik secara langsung maupun secara tidak langsung salah satunya contohnya di nagari Lunang Utara.

Nagari Lunang Utara Kecamatan Lunang Kabupaten Pesisir Selatan merupakan 1 dari 20 nagari di kecamatan lunang yang mempunyai jarak $150 \mathrm{~km}$ dari kota Kabupaten. Kecamatan Lunang sendiri merupakan salah satu dari 15 kecamatan dikabupaten pesisir selatan yang termasuk kategori kecamatan miskin dengan mayoritas penduduknya bekerja sebagai petani atau berkebun. Nagari lunang utara berdiri sejak dimekarkan pada bulan September 2009 yang terdiri dari 2 kampung yaitu kampung kumbung I dan kampung kumbung II dengan jumlah penduduknya terdiri dari 1.744 jiwa (395 KK) dan dengan penyelenggara pemerintahnya terdiri dari Wali Nagari dan perangkat nagari (sekretaris nagari, kepala urusan dan kepala kampung).

Adapun struktur aparatur pemerintah nagari lunang utara diantaranya adalah sebagai berikut:

Tabel 1.1

Aparatur Pemerintahan Nagari Lunang Utara

\begin{tabular}{|l|l|l|l|}
\hline NO & NAMA APARATUR & \multicolumn{1}{|c|}{ JABATAN } & KET \\
\hline 1 & Etriadi & Wali Nagari & \\
\hline 2 & Azali, Se & Sekretaris Nagari & \\
\hline 3 & Fahmizar & Kepala Seksi Pemerintahan & \\
\hline 4 & Aldi Rifaldo & Kaur Perencanaan & \\
\hline
\end{tabular}




\begin{tabular}{|l|l|l|l|}
\hline 5 & Andra Kusnadi & Kaur Tata Usaha Dan Umum & \\
\hline 6 & Thaiyibah & Kaur Keuangan & \\
\hline 7 & Suriati Lena Tati & Kasi & \\
\hline 8 & Sutri Yeni & Staf Nagari & \\
\hline 9 & Arlina Friska & Staf Bamus & \\
\hline 10 & Jumar & Kepala Kampung Kumbung 1 & \\
\hline 11 & Abdul Basir & Kepala Kampung Kumbung II & \\
\hline \multicolumn{4}{|c|}{ Sumber : Kantor wali Nagari Lunang Utara } \\
\hline
\end{tabular}

Mengacu pada georafis dari nagari lunang utara tersebut diatas, penulis bermaksud ingin melakukan suatu penelitian pada nagari atau desa tersebut dengan rentang waktu mulai dari Juli 2020 sampai dengan Agustus 2020.

Berdasarkan pengamatan sementara penulis dilapangan yaitu di Nagari lunang utara tentang kinerja aparatur pemerintah nagari (desa) terhadap pelayanan masyarakat, penulis menemukan kelemahan dari kinerja pemerintahannya Salah satunya disebabkan oleh adanya sumber daya aparatur pemerintah desa yang belum sepenuhnya memadai seperti masih ada aparatur pemerintah nagari yang belum bisa menggunakan teknologi seperti komputer sehingga dalam hal pemberian pelayanan publik tidak sesuai dengan prosedur pelayanan publik yang telah ditetapkan di Kantor Wali Nagari Lunang Utara yang akhirnya dapat berdampak pada kurang efektif dan efisiennya pelayanan yang diberikan oleh pemerintah nagari terhadap masyarakat, dan produktivitas pelayanan menjadi tidak maksimal.

Selain itu penulis juga menemukan permasalah lain diantaranya seperti : aparatur Pemerintah Nagari Lunang Utara masih belum maksimal dalam melakukan inovasi terkait pelayanan publik, sehingga banyak masyarakat yang mengeluhkan pelayanan yang dilakukan pemerintah di nagari tersebut dan juga Pemerintah masih kurang responsif dalam menanggapi keluhan masyarakat terkait pelayanan yang diberikan dikarenakan belum adanya kotak saran yang disediakan oleh pemerintah Nagari guna menampung kritik dan saran dari masyarakat, serta masih ada petugas yang tidak sesuai dengan prosedur pelayanan contohnya ketika masyarakat meminta pelayanan jam delapan pagi, akan tetapi pemerintah Nagari baru datang jam sembilan pagi, sehingga membuat masyarakat menunggu lama.

Berdasarkan uraian singkat dari latar belakang masalah tersebut diatas maka saya selaku peneliti merasa bahwa kinerja aparatur pemerintah nagari Lunang Utara belum optimal dalam memberikan pelayanan terhadap masyarakat di nagari lunang utara, maka dari fenomena tersebut penulis tertarik untuk mengangkat menjadi sebuah penelitian dengan judul " Analisis Hubungan Kinerja Aparatur Pemerintah Nagari Terhadap Pelayanan Masyarakat Di Nagari Lunang Utara Kecamatan Lunang Kabupaten Pesisir Selatan"

\subsection{Perumusan Masalah}

Berdasarkan atas latar belakang masalah diatas maka dapat dirumuskan masalah sebagai berikut:

1. Apakah terdapat hubungan antara kinerja aparatur pemerintah Nagari terhadap pelayanan masyarakat di Nagari Lunang Utara Kecamatan Lunang Kabupaten Pesisir Selatan? 
2. Bagaimana Tingkat hubungan kinerja aparatur pemerintah Nagari terhadap pelayanan masyarakat di Nagari Lunang Utara Kecamatan Lunang Kabupaten Pesisir Selatan?

\subsection{Tujuan Penelitian}

Adapun tujuan dari penelitian ini adalah:

1. Untuk mengetahui apakah terdapat hubungan antara kinerja aparatur pemerintah Nagari terhadap pelayanan masyarakat di Nagari Lunang Utara Kecamatan Lunang Kabupaten Pesisir Selatan.

2. Untuk mengetahui tingkat hubungan kinerja aparatur pemerintah Nagari terhadap pelayanan masyarakat di Nagari Lunang Utara Kecamatan Lunang Kabupaten Pesisir Selatan.

\subsection{Manfaat Penelitian}

\subsubsection{Manfaat akademis}

1) Sebagai salah satu syarat mahasiswa untuk memperoleh gelar sarjana administari publik (S.AP) pada strata 1 (S1) di sekolah tinggi ilmu administrasi Negara nusantara sakti (STIA-NUSA) sungaipenuh.

2) Sebagai masukan untuk pengembangan penelitian lebih lanjut terutama halyang berkenaan dengan kinerja aparat pemerintah nagari lunang utara terhadap pelayanan masyarakat

3) Untuk dapat menjadi bahan bacaan pada perpustakaan sekolah tinggi ilmu administrasi Negara nusantara sakti (STIA-NUSA) sungai penuh.

\subsubsection{Manfaat Praktis}

1) Sebagai masukan bagi nagari-nagari lain untuk melakukan pemekaran

2) Untuk menambah wawasan dan ilmu pengetahuan bagi penulis khususnya dan bagi pembaca umumnya.

\subsection{Tinjauan Pustaka}

\section{Konsep Kinerja}

Kinerja pada dasarnya dapat dilihat dari dua segi, yaitu kinerja pegawai (perindividu) dan kinerja organisasi. Kinerja pegawai adalah hasil kerja perseorangan dalam suatu organisasi. Sedangkan kinerja organisasi adalah totalitas hasil kerja yang dicapai suatu organisasi.

Kata "kinerja" telah menjadi kata yang telah memasyarakat, seringkali istilah kinerja ini, mulai dari media massa, pejabat birokrasi, pelaku bisnis bahkan sampai masyarakat awam, namun demikian tidak ditemukan defenisi yang definitive tentang kinerja. Hal ini dikarenakan istilah kinerja tidak ditemui dalam Kamus Besar Bahasa Indonesia. Kecuali kamus bahasa Indonesia lainnya yang menyatakan bahwa kinerja merupakan sesuatu yang dicapai atau prestasi yang diperlihatkan atas kemampuan kerja.Dalam Kamus Bahasa Indonesia dikemukakan arti kinerja sebagai "(1) sesuatu yang dicapai; (2) prestasi yang diperlihatkan; (3) kemampuan kerja". Sehingga berbagai pihak cenderung memberikan padanan kata kinerja dengan 'performance' dalam bahasa Inggris.

Adapun pengertian kinerja, yang dikemukakan oleh Agus Dharma yaitu sebagai berikut: "Kinerja pegawai adalah sesuatu yang dicapai oleh pegawai, prestasi kerja yang diperhatikan oleh pegawai, kemampuan kerja berkaitan dengan penggunaan peralatan kantor".

Lembaga Administrasi Negara Republik Indonesia disingkat LAN-RI (1999:3), merumuskan kinerja adalah gambaran tingkat pencapaian pelaksanaan suatu kegiatan, program, kebijaksanaan dalam mewujudkan sasaran, tujuan, misi dan visi organisasi. 
Sejalan dengan pengertian tersebut, A.A. Anwar Prabu Mangkunegara mengatakan bahwa Kinerja Karyawan (Prestasi Kerja) adalah hasil kerja secara kualitas dan kuantitas yang dicapai oleh seorang karyawan dalam melaksanakan tugasnya sesuai dengan tanggung jawab yang diberikan kepadanya.

\section{Kriteria Pengukuran Kinerja}

Begitu pentingnya penilaian kinerja bagi keberlangsungan organisasi dalam mencapai tujuan, maka perlu adanya indikator pengukuran kinerja yang dipakai secara tepat dalam organisasi tertentu. Teori kinerja dari Agus Dwiyanto dalam buku Reformasi Birokrasi Publik di Indonesia terdapat indikator kinerja, yaitu:

\section{Produktivitas}

karaktaristik-karaktaristik kepribadian individu yang muncul dalam bentuk sikap mental dan mengandung makna keinginan dan upaya individu yang selalu berusaha untuk meningkatkan kualitas kehidupannya.

2. Kualitas layanan

Banyak pandangan negatif yang terbentuk mengenai organisasi public, muncul karena ketidakpuasan masyarakat terhadap kualitas layanaan yang diterima dari organisasi publik. Dengan demikian kepuasan dari masyarakat bisa mejadi parameter untuk menilai kinerja organisasi publik.

3. Responsivitas

kemampuan organisasi untuk mengenali dan memenuhi kebutuhan masyarakat. Responsivitas perlu dimasukan ke dalam indicator kinerja karena menggambarkan secara langsung kemampuan organisasi pemerintah dalam menjalankan misi dan tujuannya.

4. Responsibilitas

Responsibilitas menjelaskan apakah pelaksanaan kegiatan organisasi publik itu dilakukan sesuai dengan prinsip-prinsip administrasi yang benar atau sesuai dengan kebijakan organisasi,baik yang eksplisit maupun implisit.

5. Akuntabilitas

Akuntabilitas publik menunjukkan pada berapa besar kebijakan dan kegiatan organisasi publik tunduk pada pejabat politik yang dipilih oleh rakyat. Dalam konteks ini, konsep akuntabilitas publik dapat digunakan untuk melihat berapa besar kebijakan dan kegiatan organisasi publik itu konsisten dengan kehendak masyarakat banyak. (Dwiyanto, 2008:50-51).

Berdasarkan pengertian kinerja pemerintahan di atas, maka kinerja pemerintahan berarti sekelompok orang dalam organisasi dengan wewenang dan tanggung jawab masingmasing dalam rangka mencapai tujuan atau sekumpulan orang dan individu yaitu pegawai negeri yang berada pada badan atau lembaga pemerintah yang menjalankan fungsi atau tugas pemerintahan. Melihat latar belakang masalah yang telah dibahas pada bab sebelumnya, maka peneliti menggunakan teori dari agus dwiyanto mengenai penilaian kinerja yang meliputi : produktivitas, kualitas layanan, akuntabilitas responsibilitas dan responsivitas.

\section{Konsep Pelayanan Publik}

Dalam Peraturan Pemerintah Nomor 96 Tahun 2012 Tentang Pelayanan Publik dikatakan Pelayanan Publik adalah kegiatan atau rangkaian kegiatan dalam rangka pemenuhan kebutuhan pelayanan sesuai dengan peraturan perundang- undangan bagi setiap warga negara dan penduduk atas barang, jasa, dan/atau pelayanan administratif yang disediakan oleh penyelenggara pelayanan publik.

Dalam pelaksanaannya pelayanan public mempuyani 3 (tiga) ruang lingkup yakni dalam pasal 3 PP no. 96 tahun 2012 menyebutkan : 
Ruang lingkup Pelayanan Publik meliputi:

a. pelayanan barang publik;

b. pelayanan jasa publik; dan

c. pelayanan administratif.

Pelayanan barang publik sebagaimana dimaksud dalam Pasal 3 huruf a meliputi:

a. Pengadaan dan penyaluran barang publik yang dilakukan oleh instansi pemerintah yang sebagian atau seluruh dananya bersumber dari anggaran pendapatan dan belanja negara dan/atau anggaran pendapatan dan belanja daerah;

b. Pengadaan dan penyaluran barang publik yang dilakukan oleh suatu badan usaha yang modal pendiriannya sebagian atau seluruhnya bersumber dari kekayaan negara dan/atau kekayaan daerah yang dipisahkan; dan

c. Pengadaan dan penyaluran barang publik yang pembiayaannya tidak bersumber dari anggaran pendapatan dan belanja negara atau anggaran pendapatan dan belanja daerah atau badan usaha yang modal pendiriannya sebagian atau seluruhnya bersumber dari kekayaan negara dan/atau kekayaan daerah yang dipisahkan, tetapi ketersediaannya menjadi Misi Negara yang ditetapkan.

Dalam Keputusan Menteri PAN Nomor: 63/KEP/M.PAN/7/2003 tentang Pedoman Umum penyelenggaraan Pelayanan Publik yang kemudian dicantumkan juga dalam Keputusan Menteri Pendayagunaan Aparatur Negara No. 25 tahun 2004 tentang pedoman umum Penyusunan indeks kepuasan Masyarakat Unit Pelayanan Instansi pemerintah disebutkan.

1. Prinsip Pelayanan Publik

a) Kesederhanaan Pelayanan

b) Kejelasan dan Kepastian Pelayanan

c) Keamanan dalam Pelayanan

d) Keterbukaan dalam Pelayanan

e) Efisiensi dalam Pelayanan

f) Ekonomis dalam Pelayanan

g) Keadilan yang Merata dalam Pelayanan

h) Ketepatan Waktu dalam Pelayanan

\section{METODE PENELITIAN}

\subsection{Pendekatan Penelitian}

Penelitian studi kasus ini menggunakan penelitian pendekatan kuantitatif dan kualitatif. analisa kuantitatif dalam penelitian ini diperlukan guna memberi gambaran hasil penelitian. Selanjutnya guna memperkuat adanya suatu korelasi variabel itu, maka memerlukan pembuktian analisa dilakukan terhadap jawaban hasil angket yang disebar kepada responden.

\subsection{Populasi dan Sampel}

\subsubsection{Populasi}

Populasi adalah semua unit analisis yang akan diteliti baik lembaga maupun perorangan dalam wujud manusia sebagaimana yang dikemukakan Sugiono (2003:90) bahwa Populasi adalah wilayah generalisasi yang terdiri atas objek / subjek yang mempunyai kualitas dan karakteristik yang ditetapkan oleh peneliti untuk dipelajari dan kemudian ditarik kesimpulannya. 
Menurut pendapat di atas, maka penulis Menyatakan Hubungan Kinerja Aparat pemerintah Nagari Terhadap pelayanan masyarakat Di Nagari Lunang Utara Kecamatan Lunang Kabupaten pesisir selatan untuk dijadikan populasi berjumlah 1.744 jiwa atau 395 KK.

\subsubsection{Sampel}

Menurut Sugiyono (2006:91) pengertian sampel adalah sebagian dari jumlah populasi yang ada. Sedangkan sampel menurut Arikunto (1996:104) sampel adalah sebagian individu yang diselidiki dari keseluruhan individu penelitian. Sugiyono (2011: 81) mendefinisikan sampel sebagai : Bagian jumlah dan karakteristik yang dimiliki populasi tersebut. Bila populasi besar dan peneliti tidak mungkin semua yang ada pada populasi, misalnya karena keterbatasan dana, tenaga, dan waktu, maka peneliti dapat menggunakan sampel yang diambil dari populasi tersebut. Untuk itu sampel diambil dari populasi harus benar-benar representative (mewakili).

Dalam penelitian ini peneliti menggunakan metode cluster random sampling. Menurut Margono (2004: 127), teknik ini digunakan bilamana populasi tidak terdiri dari individu-individu, melainkan terdiri dari kelompok-kelompok individu atau Populasi homogen Sampel yang representatif diambil secara random cluster. Teknik sampling daerah digunakan untuk menentukan sampel bila objek yang akan diteliti atau sumber data sangat luas, misalnya penduduk dari suatu negara, propinsi atau kabupaten.

Besarnya sampel dalam penelitian ini ditentukan dengan rumus Slovin sebagai berikut:

$$
\mathrm{n}=\frac{\mathrm{N}}{1+\mathrm{Ne}^{2}}
$$

dimana: $\mathrm{n}=$ jumlah elemen / anggota sampel

$\mathrm{N}=$ jumlah elemen / anggota populasi

$\mathrm{e}=$ error level (tingkat kesalahan)

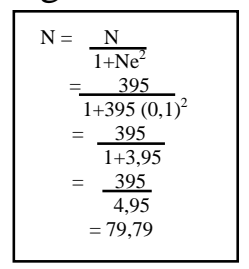

Populasi yang terdapat dalam penelitian ini berjumlah $395 \mathrm{KK}$ dan presisi yang ditetapkan atau tingkat signifikansi $10 \%$ atau 0,1 , maka besarnya sampel pada penelitian ini adalah:= 79,79 dibulatkan menjadi $80 \mathrm{Jadi}$, jumlah keseluruhan responden dalam penelitian ini adalah $80 \mathrm{KK}$.

\subsubsection{Responden}

Responden dalam penelitian ini adalah masyarakat di Nagari Lunang Utara Kecamatan Lunang Kabupaten pesisir Selatan, karena masyarakatlah yang secara langsung merasakan kinerja aparat pemerintahan Nagari dalam memberikan pelayanan terhadap masyarakatnya sendiri.

\subsection{Teknik dan Alat pengumpulan Data yang digunakan}

\section{1) Teknik Pengumpulan Data}

Teknik pengumpulan data yang dilakukan dengan cara peneliti langsung ke lokasi / objek penelitian, meliputi penyebaran angket / kuisioner.

\section{2) Alat Pengumpulan Data}

Menurut Arikunto (2004:78) penulis sangat berperan dalam seluruh proses penelitian, mulai dari memilih topik, mendeteksi topik tersebut, mengumpulkan data, hingga analisis, menginterpretasikan dan menyimpulkan hasil penelitian. Dalam mengumpulkan data data penulis membutuhkan alat yang digunakan seperti angket / kuisioner, Kertas, pena dan pensil.

\section{3) Skala Likert}

Menurut Ridwan (2001:12) Skala Likert digunakan untuk mengukur sikap, pendapat, pengaruh dan persepsi seseorang atau sekelompok orang tentang kejadian atau gejala social. 
penggunaan Skala Likert dalam penelitian ini dengan tingkatan "Sangat setuju sampai dengan sangat tidak setuju". Dengan klasifikasi sebagai berikut:

a. Sangat setuju : diberi skor $=4$

b. Setuju : diberi skor $=3$

c. Tidak Setuju : diberi skor $=2$

d. Sangat Tidak Setuju : diberi skor $=1$

\subsection{Analisis Data}

\section{1) Korelasi Produk Moment}

Untuk melihat hubungan kinerja aparat pemerintah nagari maka digunakan Korelasi produk Moment dengan menggunakan Korelasi produk Moment mengacu pada Ridwan (1997:123) adalah sebagai berikut:

$$
r=\frac{n\left(\sum x Y\right)-\left(\sum x\right) \cdot\left(\sum Y\right)}{\left.\sqrt{\left\{n \cdot \sum x^{2}\left(\sum x\right)^{2}\right\} \cdot\left\{n \cdot \sum Y^{2}\left(\sum Y\right)^{2}\right.}\right\}}
$$

$r=$ Koefisien Korelasi produk Moment

$x=$ Variabel Bebas

$\mathrm{Y}=$ Variabel Terkait

$\mathrm{n}=$ Jumlah Responden

Untuk menginterpretasikan tingkat hubungan antara variabel bebas yaitu Hubungan Kinerja Aparatur pemerintahan Nagari dengan variabel terikat yaitu pelayanan Masyarakat, penulis berpedoman pada pendapat Ridwan (2004:218).

Tabel 1.2

Interpretasi Koefisien Korelasi Nilai $\mathbf{r}$

\begin{tabular}{|c|c|}
\hline Interval Koefisien & Tingkat Hubungan \\
\hline $0,000-0,199$ & Sangat Rendah \\
$0,200-0,399$ & Rendah \\
$0,400-0,599$ & Cukup \\
$0,600-0,799$ & Kuat \\
$0,800-0,100$ & Sangat Kuat \\
\hline
\end{tabular}

Sumber : Ridwan (2004:218)

\section{2) Uji Hipotesis}

sedang kan untuk menguji hipotesis yang telah dikemukakan, maka dilakukan uji (t) dengan rumus yang mngacu pada Riduwan (2004:180) sebagai berikut:

$t_{h}=\frac{r \sqrt{n-2}}{\sqrt{1}-r 2}$

$\mathrm{t}_{\mathrm{h}}=\mathrm{t}$ Hitung

$\mathrm{r}^{2}=$ Koefisien Korelasi produk Moment

$\mathrm{n}=$ Jumlah sampel dimana sampel sama dengan populasi

Alat yang digunakan dalam pembuktian hipotesis adalah uji t hitung dengan kriteria sebagai berikut:

1. $\mathrm{t}$ hitung > t tabel maka hipotesa nol ditolak dan hipotesa alternativ diterima artinya ada Hubungan Kinerja Aparatur pemerintahan Nagari dengan variabel terikat yaitu pelayanan Masyarakat Nagari Lunang Utara Kecamatan Lunang Kabupaten pesisir Selatan.

2. $\mathrm{t}$ hitung $<\mathrm{t}$ tabel maka hipotesa nol diterima dan hipotesa alternativ ditolak artinya tidak ada Hubungan Kinerja Aparatur pemerintahan Nagari dengan variabel terikat yaitu 
pelayanan Masyarakat Nagari Lunang Utara Kecamatan Lunang Kabupaten pesisir selatan.

Sedangkan untuk mncari t tabel data dicari dengan rumus :

$\mathrm{t}$ tab $=(0,5-\alpha / 2)$

$\mathrm{t}$ tab $=\mathrm{t}$ tabel

$\mathrm{t}$ tab $=$ kesalahan nyata dalam hal ini ditentukan 5\%

Dari hasil analisis tersebut, apabila dikemukakan hasil t hitung lebih besar dari tabel berarti adanya Hubungan Kinerja Aparatur pemerintahan Nagari ( variabel X) dengan pelayanan masyarakat (variabel Y).

\subsection{Unit Analisis}

Unit analisis adalah satuan yang diteliti yang dapat berupa individu, kelompok, atau suatu latar peristiwa sosial seperti misalnya aktivitas individu atau kelompok sebagai subjek penelitian. Unit analisis yang dimaksud dalam penelitian ini adalah kinerja aparatur pemerintah nagari terhadap pelayanan masyarakat dinagari Lunang Utara Kecamatan Lunang kabupaten Pesisir Selatan.

\subsection{Lokasi Penelitian}

Pada penelitian ini penulis mengambil lokasi penelitian adalah di Nagari Lunang Utara Kecamatan Lunang Kabupaten pesisir selatan. Peneliti mengambil lokasi penelitian di nagari lunang utara kecamatan lunang kabupaten pesisir selatan provinsi sumatera barat ini karena peneliti sangat tertarik untuk mengetahui bagaimana hubungan kerja antara aparatur pemerintah nagari lunang utara terhadap pelayanan yang diberikan kepada masyarakat setempat.

\section{HASIL DAN PEMBAHASAN}

\subsection{Analisis Data}

\subsubsection{Korelasi Produk Momen}

Berdasarkan data hasil penelitian yang digambarkan pada table lampiran dengan menggunakan rumus Pearson Product Moment (PPM) maka Koefisien Korelasi (rxy) antara variable $(\mathrm{x})$ dengan variable $(\mathrm{y})$ adalah sebagai berikut:

$$
\begin{aligned}
\operatorname{rxy} & =\frac{\mathrm{n}\left(\sum \mathrm{xY}\right)-\left(\sum \mathrm{x}\right) \cdot\left(\sum \mathrm{Y}\right)}{\sqrt{\left\{\mathrm{n} \cdot \sum \mathrm{x}^{2}\left(\sum \mathrm{x}\right)^{2}\right\} \cdot\left\{\mathrm{n} \cdot \sum \mathrm{Y}^{2}\left(\sum \mathrm{Y}\right)^{2}\right\}}} \\
& =\frac{80(125908)-(3505)(2840)}{\sqrt{\left(80 \cdot 156047-(3505)^{2}\right) \cdot\left(80.102854-(2840)^{2}\right.}} \\
& =\frac{10072640-9954200}{\sqrt{(12483760-12285025) \cdot(8228320-8065600)}} \\
& =\frac{118440}{\sqrt{(198735) \cdot(162720)}} \\
& =\frac{118440}{\sqrt{32338159200}} \\
& =\frac{118440}{179828} \\
& =\mathbf{0 , 6 5 8 \quad ( r \neq 0 )}
\end{aligned}
$$

Dari perhitungan diatas diketahui terdapat hubungan antara indicator kinerja aparatur pemerintah nagari dengan kualitas pelayanan di nagari lunang utara. 
Besar nya tingkat hubungan antara variable indicator kinerja aparatur pemerintah nagari (variable bebas) terhadap kualitas pelayanan masyarakat (variable terikat) diketahui nilai $r_{x y}=0,658$ dimana koefisien korelasi ini berada pada interval angka 0,600-0799 yang berarti menunjukan tingkat hubungan yang kuat, jadi dapat disimpulkan bahwa terdapat tingkat hubungan yang kuat antara kinerja aparatur pemerintah nagari terhadap pelayanan masyarakat di Nagari Lunang Utara Kecamatan Lunang Kabupaten Pesisir Selatan Provinsi Sumatera Barat.

Berdasarkan hasil penelitian, tingkat hubungan yang kuat antara kinerja aparatur pemerintah nagari terhadap kualitas pelayanan masyarakat di Nagari Lunang Utara Kecamatan Lunang Kabupaten Pesisir Selatan dilihat pada pernyataan no 1 (variable x) bahwa aparatur pemerintah nagari mengerjakan suatu pekerjaan dengan penuh rasa tanggung jawab,dan hasil penelitian penulis menunjukan 4 dari 80 orang yang telah diteliti oleh penulis menjawab sangat setuju, 38 orang menjawab setuju, 37 orang menjawab tidak setuju dan hanya 1 orang yang menjawab sangat tidak setuju

Pada pernyataan no 2 (variable $\mathrm{x}$ ) bahwa kemampuan, pengetahuan dan latar belakang pendidikan yang dimiliki oleh aparatur pemerintah nagari lunang utara sesuai dengan pekerjaan dan tugas yang sedang mereka jalani, dari pernyataan ini tidak ada satu orang pun yang menjawab sangat setuju, 16 orang menjawab setuju, 57 orang menjawab tidak setuju dan 7 orang menjawab sangat tidak setuju.

Pada pernyataan no 3 (variable $\mathrm{x}$ ) bahwa hasil kerja aparatur pemerintah nagari sesuai dengan kualitas yang telah ditentukan, 2 dari 80 orang menjawab sangat setuju, 20 orang menjawab setuju, 49 menjawab tidak setuju dan 9 orang menjawab sangat tidak setuju. Pada pernyataan no 4 (variable $\mathrm{x}$ ) bahwa kuantitas kerja aparatur pemerintah sudah sesuai dengan standar kerja yang diharapkan oleh masyarakat, 2 dari 80 orang menjawab sangat setuju, 25 orang setuju, 42 orang menjawab tidak setuju dan 11 orang menjawab sangat tidak setuju.

Pada pernyataan no 5 (variable x) bahwa selama bekerja sebagai aparatur pemerintah di nagari lunang utara ini, hasil pekerjaan dan pencapaian mereka lebih baik dari aparat pemerintah sebelumnya, dari pernyataan ini ada 12 orang yang menjawab sangat setuju, 59 orang menjawab setuju, 8 orang menjawab tidak setuju dan hanya 1 orang yang menjawab sangat tidak setuju. Pada pernyataan no 6 (variable $\mathrm{x}$ ) bahwa aparatur pemerintah nagari bekerja dengan penuh semangat, ada 7 daro 80 orang menjawab sangat setuju, 61 orang menjawab setuju, 12 orang tidak setuju dan tidak ada yang menjawab sangat tidaak setuju.

Pada pernyataan no 7 (variable $\mathrm{x}$ ) bahwa Seluruh bentuk pekerjaan selama ini dapat di kerjakan dan hasilnya sesuai dengan waktu yang telah direncanakan, 4 orang yang menyatakan sangat setuju dengan pernyataan ini, 45 orang setuju, 31 orang tidak setuju dan tidak ada yang menjawab sangat tidak setuju. Pada pernyataan no 8 (variable $\mathrm{x}$ ) bahwa mereka mampu menggunakan waktu dengan efisien dalam melaksanakan tugas sebagai aparatur pemerintah nagari, hanya 1 orang dari 80 responden yang menyatakan sangat setuju, 27 orang menjawab setuju, 50 orang menjawab tidak setuju dan 2 orang yang sangat tidak setuju.

Pada pernyataan no 9 (variable x) bahwa aparatur pemerintah nagari bekerja sesuai dengan prosedur dan jadwal seperti datang dan pulang kantor tepat pada waktunya, pernyataaan ini hanya 2 orang dari 80 responden yang menjawab sangat setuju, 29 orang setuju, 32 orang tidak setuju dan ada 17 orang yang menyatakan sangat tidak setuju.

Pada pernyataan no 10 (variable x) bahwa aparatur pemerintah nagari mempunyai komitmen dan tanggungjawab dalam bekerja, pernyataan ini mendapatkan 3 dari 80 responden yang menjawab sangat setuju, 30 yang setuju, 38 orang tidak setuju dan 9 orang yang sangat tidak setuju. Pada pernyataan no 11 (variable $\mathrm{x}$ ) bahwa aparatur pemerintah nagari selalu mengayomi masyarakat secara baik, 2 orang menjawab sangat setuju, 54 orang 
menjawab ssetuju, 18 orang tidak setuju dan ada 6 orang yang sangat tidak setuju. Pada pernyataan no 12 (variable $\mathrm{x}$ ) bahwa aparatur pemerintah nagari bersedia bekerja diluar jam kantor jika masyarakat membutuhkan, pernyataan ini mendapatakan 2 orang yang menjawab sangat setuju, 27 orang yang setuju, 39 orang yang tidak setuju dan ada 12 orang yang sangat tidak setuju.

Pada pernyataan no 13 (variable x) bahwa aparatur pemerintah nagari mampu bekerja sendiri tanpa bergantung pada rekan kerja yang lain, 1 orang yang menjawab sangat setuju, 27 yang setuju, 34 orang yang tidak setuju, dan 18 orang yang menjawab sangat tidak setuju. Pada pernyataan no 14 (variable x) bahwa aparatur pemerintah nagari mampu memilih dan melihat masalah dari sudut pandang yang berbeda dengan yang lain, 4 orang yang menjawab sangat setuju, 17 orang setuju, 41 orang tidak setuju dan ada 18 orang yang menyatakan sangat tidak setuju. Pada pernyataan no 15 (variable $\mathrm{x}$ ) bahwa aparatur pemerintah nagari sangat jarang meminta bantuan oarng lain untuk melakukan pekerjaan mereka, pernyataan ini mendapatkan 2 orang yang menjawab sangat setuju, 20 setuju, 35 orang yang tidak setuju dan 23 orang yang sangat tidak setuju.

Pada pernyataan no 16 (variable x) bahwa aparatur pemerintah nagari mengambil keputusan secara bersama sama, 14 orang menyatakan sangat setuju, 18 orang yang setuju, 19 orang yang tidak setuju dan 29 orang sangat tidak setuju. Pada pernyataan no 17 (variable x) bahwa wali nagari beserta staf berkomitmen menjalankan tugas secara bersama, hal ini mendapatkan 3 orang yang menyatakan sangat setuju, 49 orang yang setuju, 25 orang tidak setuju dan ada 3 orang yang sangat tidak setuju. Pada pernyataan no 18 (variable $\mathrm{x}$ ) bahwa Setiap staf pemerintah memiliki komitmen untuk memajukan dan mensejahterakan nagari (desa) secara bersama sama, ada 8 orang yang sangat setuju, 49 orang setuju, 22 orang tidak setuju dan hanya 1 orang yang menjawab sangat tidak setuju.

pada pernyataan no 1 (variable y) bahwa aparatur pemerintah nagari memberikan respon secara tepat terhadap kebutuhan masyarakat,dan hasil penelitian penulis menunjukan bahwa 2 dari 80 orang yang telah diteliti oleh penulis menjawab sangat setuju, 32 orang menjawab setuju, 43 orang menjawab tidak setuju dan hanya 3 orang yang menjawab sangat tidak setuju.

Pada pernyataan no 2 (variable y) bahwa aparatur pemerintah nagari jarang melakukan kesalahan dalam pendataan dan mengerjakannya dengan baik, dari pernyataan ini ada 1 orang yang menjawab sangat setuju, 33 orang menjawab setuju, 23 orang menjawab tidak setuju dan 23 orang menjawab sangat tidak setuju.

Pada pernyataan no 3 (variable y) bahwa aparatur pemerintah nagari melayani masyarakat secara ramah dan santun, 4 dari 80 orang menjawab sangat setuju, 61 orang menjawab setuju, 11 menjawab tidak setuju dan 4 orang menjawab sangat tidak setuju. Pada pernyataan no 4 (variable y) bahwa aparatur pemerintah nagari selalu menyampaikan informasi secara jelas kepada masyarakat, 4 dari 80 orang menjawab sangat setuju, 35 orang setuju, 40 orang menjawab tidak setuju dan hanya 1 orang menjawab sangat tidak setuju.

Pada pernyataan no 5 (variable y) bahwa aparatur pemerintah nagari selalu merespon dengan baik apabila ada keluhan dari masyarakat, dari pernyataan ini ada 3 orang yang menjawab sangat setuju, 19 orang menjawab setuju, 27 orang menjawab tidak setuju dan 30 orang yang menjawab sangat tidak setuju. Pada pernyataan no 6 (variable y) bahwa aparatur pemerintah nagari melakukan pelayanan administrasi secara cepat dan tepat, ada 4 dari 80 orang menjawab sangat setuju, 19 orang menjawab setuju, 27 orang tidak setuju dan 30 orang yang menjawab sangat tidaak setuju.

Pada pernyataan no 7 (variable y) bahwa Aparatur pemerintah nagari memberikan informasi yang jelas dalam melayani masyarakat, 5 orang yang menyatakan sangat setuju dengan pernyataan ini, 28 orang setuju, 40 orang tidak setuju dan 7 orang yang menjawab 
sangat tidak setuju. Pada pernyataan no 8 (variable y) bahwa mereka mampu menggunakan waktu dengan efisien dalam melaksanakan tugas sebagai aparatur pemerintah nagari, hanya 1 orang dari 80 responden yang menyatakan sangat setuju, 27 orang menjawab setuju, 50 orang menjawab tidak setuju dan 2 orang yang sangat tidak setuju.

Pada pernyataan no 9 (variable x) bahwa aparatur pemerintah nagari mampu meyakini masyarakat dalam melakukan pelayanan tanpa rasa ragu, pernyataaan ini hanya 8 orang dari 80 responden yang menjawab sangat setuju, 37 orang setuju, 33 orang tidak setuju dan ada 2 orang yang menyatakan sangat tidak setuju.

Pada pernyataan no 10 (variable y) bahwa adanya jaminan rasa aman saat melakukan pelayanan, pernyataan ini mendapatkan 4 dari 80 responden yang menjawab sangat setuju, 27 yang setuju, 39 orang tidak setuju dan 10 orang yang sangat tidak setuju.

Pada pernyataan no 11 (variable y) bahwa aparatur pemerintah nagari selalu menghormati dan memberikan perhatian kepada masyarakat yang membutuhkan pelayanan, 3 orang menjawab sangat setuju, 22 orang menjawab ssetuju, 25 orang tidak setuju dan ada 30 orang yang sangat tidak setuju. Pada pernyataan no 12 (variable y) bahwa aparatur pemerintah nagari lebih mengutamakan kepentingan masyarakat ketimbang kepentingan pribadi, pernyataan ini mendapatakan 3 orang yang menjawab sangat setuju, 12 orang yang setuju, 31 orang yang tidak setuju dan ada 33 orang yang sangat tidak setuju.

Pada pernyataan no 13 (variable y) bahwa Sarana dan prasaran di kantor wali nagari Lunang Utara sangat memadai, dari pernyataan ini ada 2 orang yang menjawab sangat setuju, 6 yang setuju, 15 orang yang tidak setuju, dan 57 orang yang menjawab sangat tidak setuju.

Pada pernyataan no 14 (variable y) bahwa Seluruh aparatur pemerintah nagari Lunang utara menggunakan pakaian (seragam) yang rapi dan sopan, 5 orang yang menjawab sangat setuju, 62 orang setuju, 13 orang tidak setuju dan tidak ada orang yang menyatakan sangat tidak setuju.

Pada pernyataan no 15 (variable y) bahwa Kantor wali nagari lunang utara sangat bersih dan nyaman, pernyataan ini mendapatkan 15 orang yang menjawab sangat setuju, 49 setuju, 11 orang yang tidak setuju dan 5 orang yang sangat tidak setuju.

\subsubsection{Uji Signifikan}

Pengujian selanjutnya adalah pengujian signifikan yang berfungsi untuk menguji hubungan kinerja aparatur pemerintah nagari (variable $\mathrm{x}$ ) terhadap pelayanan masyarakat Nagari Lunang Utara (variable y), maka hasil korelasi produk momen diuji dengan uji $\mathrm{t}$ sebagai berikut:

$$
\begin{aligned}
\mathrm{t}_{\text {hitung }}= & \frac{\mathrm{r} \sqrt{\mathrm{n}-2}}{\sqrt{1-\mathrm{r}^{2}}} \\
= & 0,65 \sqrt{80-2} \\
= & \frac{0,65 \sqrt{78}}{\sqrt{1-(-0,4225)^{2}}} \\
= & 0,65(8,8317) \\
= & \frac{\sqrt{0,74775}}{0,759934} \\
= & 7,55
\end{aligned}
$$

Kaidah Pengujian:

Jika $t_{\text {hitung }} \geq \mathrm{t}_{\text {table }}$ maka signifikan

Jika $\mathrm{t}_{\text {hitung }} \leq \mathrm{t}_{\text {table }}$ maka tidak signifikan

Dari perhitungan diatas diperoleh nilai $\mathrm{t}_{\text {hitung }}$ sebesar 7,55 sedang kan nilai $\mathrm{t}_{\text {table }}$ dengan tingkat kesalahan $\alpha=0,05 \mathrm{db}=\mathrm{n}-2=80-2=78$ adalah 1,66 sehingga $t_{\text {hitung }}>\mathrm{t}_{\text {table }}$ yaitu 
7,55 > 1,66 dengan demikian maka berdasarkan kriteria uji signifikan, Ha diterima dan Ho ditolak artinya bahwa ada terdapat hubungan antara kinerja aparatur pemerintah nagari terhadap pelayanan masyarakat di Nagari Lunang Utara Kecamatan Lunang Kabupaten Pesisir Selatan Provinsi Sumatera barat.

\section{SIMPULAN}

\subsection{Kesimpulan}

Berdasarkan hasil dan tujuan penelitian tentang analisis hubungan kinerja aparatur pemerintah nagari terhadap pelayanan masyarakat di Nagari Lunang Utara Kecamatan Lunang Kabupaten Pesisir Selatan Provinsi Sumatera Barat, maka dapat disimpulkan sebagai berikut:

1) Berdasarkan hasil korelasi pearson produk momen (PPM) diperoleh koefisisen korelasi sebesar 0,65 dimana koefisien korelasi ini berada pada interval angka 0,600 0799 yang berarti menunjukan tingkat hubungan yang kuat, jadi dapat disimpulkan bahwa terdapat tingkat hubungan yang kuat antara kinerja aparatur pemerintah nagari terhadap pelayanan masyarakat di Nagari Lunang Utara Kecamatan Lunang Kabupaten Pesisir Selatan Provinsi Sumatera Barat. Hal ini terlihat dari respon masyarakat yang sebagian besar setuju bahwa kualitas pelayanan yang diberikan oleh aparatur pemerintah nagari sangat baik selain itu pemerintah nagari lunang utara juga telah bekerja dengan penuh semangat dan bertanggung jawab.

2) Berdasarkan hasil penelitian diketahui besarnya hubungan kinerja aparatur pemerintah nagari terhadap pelayanan masyarakat dari uji signifikasi diperoleh nilai $t_{\text {hitung }}$ sebesar 7,55 sedang kan nilai $t_{\text {table }}$ adalah 1,66 sehingga $t_{\text {hitung }}>t_{\text {table }}$ yaitu 7,55 $>1,66$ dengan demikian dapat disimpulkan bahwa terdapat hubungan antara kinerja aparatur pemerintah nagari terhadap pelayanan masyarakat di Nagari Lunang Utara Kecamatan Lunang Kabupaten Pesisir Selatan Provinsi Sumatera barat. Hal ini dapat dilihat pada keandalan dan ketanggapan aparatur pemerintah nagari dalam memberikan pelayanan kepada masyarakat dengan sangat baik.

\subsection{Saran}

Berdasarkan hasil penelitian dilapangan mengenai hubungan kinerja aparatur pemerintah nagari terhadap pelayanan masyarakat di nagari lunang utara kecamatan lunang kabupaten pesisir selatan, berikut beberapa saran yang dapat penulis sampaikan dan penulis berharap dapat menjadi alternative dalam membantu memecahkan masalah ataupun dapat meningkatkan kualitas kinerja aparatur pemerintah nagari terhadap pelayanan yang lebih baik lagi antara lain sebagai berikut:

1. Aparatur Pemerintah nagari sebaiknya sangat memperhatikan komitmen kerja yang bagus agar tercapainya tujuan membentuk nagari yang sejahtera dengan cara memberikan pelatihan serta bimbingan pada setiap aparatur pemerintah yang kurang memahami cara penggunakan teknologi serta aparatur pemerintah nagari harus lebih responsive dalam menampung ide ide baru dari masyarakat yang berguna untuk membangun nagari menjadi lebih baik lagi.

2. Dalam hal hubungan kinerja, aparatur pemerintah nagari lunang utara kecamatan lunang kabupaten pesisir selatan juga harus memperhatikan kinerja aparatur pemerintahnya dengan cara peningkatan serta pelatihan terhadap peningkatan sumber daya aparatur pemerintah nagari baik orientasi dalam maupun luar kantor pemberdayaan masyarakat. 


\section{UCAPAN TERIMAKASIH}

Diucapkan terima kasih kepada semua pihak yang telah berkontribusi dalam penulisan jurnal ini, sehingga jurnal ini dapat diselesaikan dengan baik. Dan juga terima kasih kepada penglola jurnal Qawwam, sehingga bisa dipublikasan di OJS Qawwam.

\section{DAFTAR PUSTAKA}

Arikunto, Suharsimi. 1996, Prosedur Penelitian Dan Pendekatan Praktek. Edisi Revisi III, Jakarta.Rieneka Cipta.

Arikunto, Suharsimi. 2004. Prosedur Penelitian Suatu Pendekatan Praktek. Jakarta: Rieneka Cipta.

Pebi Julianto. 2014. Evaluasi Pelaksanaan Program Satu milyar Satu kecamatan (Samisake) di kecamatan Depati Tujuh Kabupaten Kerinci Provinsi jambi tahun 2014. OSF Preprints. Jakarta.

Fahmi, Irham. 2013. Managemen Kinerja Teori Dan Aplikasi. Bandung: Alfabeta.

Kamus Besar Bahasa Indonesia, 2002. Tentang Pengertian Kinerja.

Pebi Julianto. 2020. Pengaruh Disiplin Kerja Terhadap Prestasi Kerja Pegawai pada Puskesmas di kecamatan Depati VII Kabupaten Kerinci. E Jurnal Administrasi Nusantara. Sungai Penuh.

Komarudin. 2014. Reformasi Birokrasi Dan Pelayanan Public. Bandung: Genesindo.

Kotler, Philip (2000). Prinsip -Prinsip Pemasaran Manajemen, Jakarta : Prenhalindo

Pebi Julianto. 2020. Partisipasi Masyarakat Dalam Program Bantuan Stimulan Perumahan Swadaya (BSPS) di Desa Koto Baru Kecamatan Koto baru (2020). E Jurnal Qawwam. Kerinci.

Kotler, Philip dan Kevin Lane Keller. 2009. Manajemen Pemasaran, Edisi Ketiga Belas, Jakarta : Penerbit Erlangga

Lexie. 2005. Reformasi Dan Reformasi Pegawai. CV Indra Prahasta. Bandung

Pebi Julianto. 2018. Pengaruh Sistem Kearsipan Terhadap Efisiensi Kerja Pada koantor Camat Air Hangat Kabupaten Kerinci. E Jurnal Administrasi Nusantara. Sungai Penuh.

Mariam, Rani. 2009. Pengaruh Gaya Kepemimpinan dan Budaya Organisasi terhadap Kinerja Karyawan melalui kepuasan kerja sebagai variabel intervening, studi pada PT.Asuransi Jasa Indonesia (Persero). Semarang. Tesis Universit as Diponegoro

Mukarom, Zaenal, Dan Muhibudin Wijaya Laksana. 2015. Managemen Pelayanan Public. Bandung: CV Pustaka Setia.

Pasolong, Harbani. 2010. Teori Administrasi Public. Bandung: Alfabeta

Pebi Julianto. 2018. Pengaruh Pengetahuan dan Keterampilan Terhadap Prestasi Kerja Pegawai Pada Mtsn Model Sungai Penuh. E Jurnal Administrasi Nusantara. Sungai Penuh.

Simanjutak, P. J. 2005. Managemen Dan Evaluasi Kinerja. Jakarta: FE UI

Sinambela, Lijan Poltak. 2008. Reformasi Pelayanan Public Teori, Kebijakan Dan Implementasi. Jakarta: PT Bumi Aksara

Sugiyono. 2003. Metode Penelitian. Bandung: Alfabeta

Undang Undang Nomor 25 Tahun 2009 Tentang Pedoman Umum Pelayanan Public.

Pebi Julianto. 2020. Implementasi Program Bantuan Pangan non Tunai (BPNT) di Kecamatan Sitinjau Laut Kabupaten Kerinci. E Jurnal Qawwam. Kerinci.

Kepmenpan No 63 Tahun 2003. Kualitas Pelayanan Publik.

Peraturan Daerah Provinsi Sumatra Barat Nomor 7 Tahun 2018 Tentang Nagari 
Pebi Julianto. 2021. Pengaruh hard Skill dan Pelatihan Terhadap Kinerja Aparatur Sipil Negara Pada Kantor Camat Airn Hangat Kabupaten Kerinci. E Jurnal Administrasi Mahasiswa. Sungai Penuh.

http://junaidichaniago.wordpress.com

Organisasi Sekretariat Daerah Pemerintah Kota Surabaya tentang Survey kepuasan masyarakat. 2017 